\title{
Spore Micromorphology and Anatomy of the Fern GenusHistiopterisJ. Sm. (Dennstaedtiaceae) in Peninsular Malaysia
}

\begin{abstract}
More recent classifications used mainly morphological data when Histiopteris was included as one of the genera in the family Dennstaedtiaceae. A study on spore micromorphological and anatomical studies of Histiopteris J. Sm. from Peninsular Malaysia was undertaken to provide spore micromorphological and anatomical information of the stipes, lamina and rhizomes for the genus. These information would become the source of reference and comparison for other members within the family Dennstaedtiaceae and would deem necessary in future classification considerations of Histiopteris when similar studies are carried out for all genera of the Dennstaedtiaceae in the near future.
\end{abstract}

Keyword: Spore, Micromorphology, Anatomy, Histiopteris, Peninsular Malaysia 